\section{Farm and Garden Seeds}

By Prof. S. P. Mercer. With a Section on the Seeds Act, 1920, by A. W. Munro. (Agricultural and Horticultural Handbooks.) Pp. $205+14$ plates. (London : Crosby Lockwood and Son, Ltd., 1938.) 10s. 6d. net.

P ROF. MERCER has produced an interesting and readable book on farm and garden seeds. While it may not make an appeal to a very wide public, it should find a place in the libraries of those for whom the author, in his preface, states he has attempted to cater; namely, the agricultural student, those concerned in the business of seed testing, and such others as are interested in how things grow and the methods adopted to ensure that the seeds they buy are what they purport to be and may reasonably be expected to germinate.

The book consists of five chapters, together with one appendix giving physical data about crop seeds and a second giving notes on practical seed testing. The first four chapters are by Prof. Mercer. After a short and somewhat condensed chapter on the formation, structure and growth of a seed, he goes on to give an interesting account of commercial seed production in Great Britain and indicates the sources of supply for other commercial seeds which are drawn from other countries. The chapter on seed testing bears the authoritative imprint of one who has for a number of years been in charge of an official seed-testing station. Prof. Mercer's final chapter contains a short description of each of the main crop and weeds seeds with the most beautiful and delicate illustrations of the seeds which the reviewer has ever seen. These illustrations are the author's own drawings and he is to be congratulated on them.

The final chapter in this book is contributed by Mr. Munro, of the Ministry of Agriculture, who, from intimate personal knowledge, gives an account of the provisions and administration of the Seeds Act of 1920.

An index, sufficiently comprehensive to make reference easy and quick, is included. R. R.

Biology for Pharmaceutical Students and Others By Prof. S. Mangham and A. R. Hockley. Pp. viii +613. (London : Baillière, Tindall and Cox, 1938.) $21 s$.

IKE many other introductory biology books 1 recently published, this is a comprehensive, though elementary, survey of the subject; but it is difficult to believe that the authors were sufficiently alive to the needs of those for whom the book was specifically written, namely, students preparing for the preliminary scientific examination of the Pharmaceutical Society of Great Britain. The price, and also the length, are too great for a student's book, particularly in view of the fact that it is supposed to be of a preliminary nature; no doubt the latter determined the former. One explanation of the undue length is that the authors have borne in mind the students' later needs in pharmacognosy and physiology; but to forestall this later teaching in the student's first year is doubtful policy. In fact, it does not seem feasible to expect preliminary students to assimilate profitably all that this book offers at the beginning of their professional studies.

Furthermore, especially in those parts dealing with plant physiology, there are too many names-usually surnames only - of research workers. These, too, in places seem to crop up indiscriminately. For example, in the two pages dealing with vitamins, apart from that of Hopkins, the names of Howard and Hirst only are mentioned. The account would be better balanced if these had been omitted. Again, in the section on the mechanism of photosynthesis, the first paragraph alone contains six names of workers from Priestley to Boussingault. These can mean little to a visitor to the subject. They will make little impression on his mind and can only be a useless burden to the student, for whom the volume is written.

The book contains numerous excellent illustrations.

\section{The Flight of Birds}

By C. Horton-Smith. Pp. $182+17$ plates. (London : H. F. and G. Witherby, Ltd., 1938.) 7s. 6d. net.

7 HIS book is a short popular account of bird flight. Some of its readers will be primarily interested in birds, others in aeronautics; it is perhaps inevitable that a few should be disappointed. The author is at his best when describing those attributes of the bird's wing which he has obviously studied at first-hand; he is not quite so convincing when translating the behaviour of the wing into aeronautical language. It is impossible at present to make any useful comparison between the air flow past a bird's wing during active flapping flight and that past a simple aerofoil, and it is therefore much to be regretted that Dr. Horton Smith does not always make it quite clear whether his statements apply to the wing of a bird or the 'wing' of an aeroplane.

Some of Dr. Horton-Smith's views may possibly be open to criticism on aerodynamical grounds, but as a biologist he has performed an extremely useful task in bringing into this small volume a large number of important observations which can searcely fail to stimulate an interest in the subject.

\section{Mineralogie von Bolivien}

Von Friedrich Ahlfeld und Jorge Munoz Reyes. Pp. vii $+89+1$ plate. (Berlin : Gebrüder Borntraeger, 1938.) 10.50 gold marks.

GINCE David Forbes in 1865 wrote his account of $D$ his researches in the mining districts of South America, many other British mineralogists have taken an interest in the rich mineral localities of Bolivia and the many rare species found there. A German translation of the Spanish "Mineralogia Boliviana" by Ahlfeld and Muñoz Reyes will be very welcome. In this book descriptions are given of 171 mineral species with brief mention of the places and modes of occurrence. Some of the occurrences recorded are new. There is a good index of localities, and the book is illustrated by crystal drawings and a frontispiece. 